Open Access

\title{
Textbook-assigned and self-selected topics of Iranian male EFL learners: topic interest, topic familiarity, topic importance, and topic difficulty
}

\author{
Latifeh Shakourzadeh and Siros Izadpanah *i)
}

\author{
*Correspondence: cyrosizadpanah@ \\ yahoo.com \\ Department of English Language \\ Teaching, Zanjan Branch, Islamic \\ Azad University, Zanjan, Iran
}

\begin{abstract}
In recent years, learner-centered teaching has emphasized the demand for making healthy environment where learners' preferences, interests, personal experiences, cultural backgrounds and lifestyles are taken into account when making decisions about various characteristics of language learning/teaching The choice of topics, which are used in EFL discussion classes, is considered to play an important role in learners' propensity to engage in a negotiation for meaning. This study was aimed to investigate the perception of Textbook-Assigned and Self-Selected Topics of Iranian male EFL Learners: topic interest, topic familiarity, topic importance, and topic difficulty based on correlational design. It was carried out with 200 male Intermediate EFL learners who were selected by convenience sampling. Although most teachers might be aware of the importance of a good assessment strategy on the topic interest and topic familiarity, rarely do they use it for topic importance and topic difficulty. The results of the study showed that Iranian male EFL learners mostly preferred the topics to be more interesting and familiar in both textbook-assigned $(M=3.1259, \mathrm{SD}=.21553$, Sig $=.000)$ and self-selected topics ( $M=4.0531, \mathrm{SD}=.13334$, Sig $=.000)$. In addition, there was a significant difference between the learners' perceptions of textbookassigned and self-selected topics in terms of interest and familiarity, but less difference in terms of importance and difficulty. The findings of the study indicated that learners' selection of their own topics can provide the potential implications for their willingness to participate in second and foreign language learning and take responsibility for their own learning process.
\end{abstract}

Keywords: Self-selected topics, Textbook-assigned topics, Topic difficulty, Topic familiarity, Topic importance, Topic interest (c) The Author(s). 2020 Open Access This article is licensed under a Creative Commons Attribution 4.0 International License, which permits use, sharing, adaptation, distribution and reproduction in any medium or format, as long as you give appropriate credit to the original author(s) and the source, provide a link to the Creative Commons licence, and indicate if changes were made. The images or other third party material in this article are included in the article's Creative Commons licence, unless indicated otherwise in a credit line to the material. If material is not included in the article's Creative Commons licence and your intended use is not permitted by statutory regulation or exceeds the permitted use, you will need to obtain permission directly from the copyright holder. To view a copy of this licence, visit http://creativecommons.org/licenses/by/4.0/. 


\section{Introduction}

An increase in employing learner-centered approaches to language education in the world, attention was led to learners' perception of their learning needs and to their preferred learning styles (Benson, 2007; Beschorner \& Woodward, 2020). To maximize the value of second or foreign instruction, previous researchers have noted the need to address mismatches in the perceptions, attitudes, and beliefs of teachers and learners concerning classroom aims and events (Barkhuizen, 1998; Kumaravadivelu, 1991; Matsuyama, Nakaya, Okazaki, Lebowitz, Leppink, \& Van Der Vleuten, 2019). Kumaravadivelu claimed that "the more we know about the learner's personal approaches and personal concepts, the better and more productive our intervention will be" (p. 107). Moreover, Barkhuizen (1998) and Tunalı (2019) stress that once we are aware of our students' perceptions, we can, if needed, implement alternative classroom practices.

In a learner-centered approach, the knowledge is no longer transmitted to the learners by teachers. Learners should contribute actively and take responsibility for their choices during their learning process and take control of their own learning. Tunalı stated that self-directed learner has the ability to make their choices about what and how to learn. Also, according to Benson (2003) and Bonyadi (2014) self-confidence of learners is as an important factor which makes them make decisions about their language learning .

Concerning the issue of whether to assign topics for learners' discussion activities or allow them to select the topics themselves, it seems that learners are not generally interested in developing the topics which they have not selected. In fact, when the topics of tasks are preselected and presented by curriculum developers, course materials, or teachers, the learners' interests, preferences, cultural backgrounds, personal experiences and lifestyles may not be fully taken care of. As a consequence, the learners may not have the required extent of cognitive and/or affective commitment necessary for active engagement in opinion-sharing tasks.

literature reveals several studies which have addressed the effects of different topic variables (i.e., interest, familiarity, importance, and difficulty) on various language skills (e.g., reading, speaking, and writing) and also learners' perceptions of textbook-assigned and self-selected topics (Threadkell, 2010). In all such studies, however, only learner's perceptions of the efficacy of the topics provided for them have been investigated. Nevertheless, it is worth mentioning that limiting the study to the elicitation of learners' perceptions of the topics may only reflect their theoretical or idealistic attitudes. In contrast, observing the actual behavior of learners when they are doing the textbook-assigned and self-selected tasks may be more rooted in reality and enables the researchers to investigate more deeply and in ways to be more realistic the relationship between learners' beliefs and their practices.

In general, when the topics are imposed, structured, and defined before taking into account learners' preferences and personal involvements, their motivation to develop the tasks will decrease drastically, and the task will turn to a controlled and predictable activity which fails to consider learners' values, existing knowledge, and experiences that they might bring to bear on certain aspects of the topics.

However, few research studies, if any, have been done to empirically investigate the impact of textbook-assigned and self-selected topics on EFL male learners in terms of topic interest, topic familiarity, topic importance, and topic difficulty in an EFL context. 
Despite all the research conducted by scholars mentioned above, to the best of the researchers' knowledge, the perception of self-selected topics versus textbook-assigned topics among Iranian male EFL learners based on topic difficulty, topic importance, topic familiarity, and topic interest have not been dealt with in the related literature. In order to fill this gap, this study investigated the Iranian male EFL learners' perception of this issue. This study addresses the following research questions:

1. How do Iranian EFL male learners generally view textbook-assigned topics based on the four dimensions of topic interest, topic familiarity, topic importance, and topic difficulty?

2. How do Iranian EFL male learners generally view self-selected topics based on the four dimensions of topic interest, topic familiarity, topic importance, and topic difficulty?

3. Is there any significant difference between the learners' perceptions of textbookassigned and self-selected discussion topics? If so, how do they differ?

4. Which condition (i.e. textbook assigned or self-selected tasks) contribute more to the better understanding of the discussion topics?

\section{Review of the literature}

\section{Background of learner-centeredness}

In the 1970s and 1980s, a new method of teaching language, Communicative Language Teaching (CLT) came into vogue, which was opposing traditional approaches. According to Nunan and Lamb (1996), p.67 language was viewed as "a system of rule-governed structures hierarchically arranged" in traditional approaches of the 1950s and 1960s. As stated by Anderson (2020), the language was defined as "a system for expression of meaning" in CLT.

Based on the different trends which define language and teaching in different ways, the teachers, instructors, students, and materials played different roles (Choi, Lee, \& Kim, 2019). In new methodology, learners were considered active participants who played a significant role in teaching and learning a language (Narayanan, 2020). The teachers and instructors had the role of the facilitator of the communication and they were not considered as a source of information. Teaching materials were designed based on real-life contexts and learners' possible experiences.

Nowadays, basic training of each teacher includes being responsive to their learners' needs and preferences. The learner-centeredness approach, which focuses on learners in language learning is the core of the present idea of language teaching and learning. The learners' goals of language learning and their real-life needs became the central focus of language teaching with the emergence of this new movement. This trend has resulted in a learner-centered approach in teaching and learning a language (Üzüm \& Pesen, 2019). Within the last decade, research studies have been conducted to investigate the different aspects of the teaching and learning process based on the learnercentered approach.

\section{Defining learner-centeredness}

Due to its susceptibility to elicit multiple interpretations, the concept of learner centeredness in education has been one of the most controversial topics. Some teachers 
react negatively to the concept because they feel their professional roles are devalued in the process of handing the power to learners since this may necessitate giving over to learner duties and responsibilities that rightly belong to teachers (Nunan, 2005). As Nunan (1989) observes, learner-centeredness can best be defined by highlighting one of its key characteristics that can also be considered as one of the glaring differences between learner-centered classrooms and other types of classrooms. In fact, in a learnercentered classroom, key decisions about what will be taught, how it will be taught, when it will be taught, and how it will be assessed are made with reference to the learners (Amiri \& Saberi, 2019)). Seen in this light, information about learners, and where feasible, from learners, are used in order to find an answer to the fundamental questions of what, how, when, and how well to teach a language. The characteristics of learner-centered instruction along with its specific techniques, which can be applied to curricula, have received a variety of interpretations that have been summarized as follows (Kojima, 2005, p.66):

a) Techniques that focus on or account for learners' needs, styles, and goals.

b) Techniques that give some control to the learner (e.g., group work or strategy training)

c) Curricula that include the consultation, and input of learners and that do not presuppose objectives in advance.

d) Techniques that allow for learner creativity and innovation.

e) Techniques that enhance a learner's sense of competence and self-worth.

\section{Topic}

Discussion is important to learning in all disciplines because it helps students process information rather than simply receive it. Leading a discussion requires skills different from lecturing. The goal of a discussion is to get students to practice thinking about the course material. Zuengler and Bent (1991) compared the task performances, which differed with regard to the relative importance of topic to the learners and native speakers. They found that when the topic was of little importance to the speakers, the learners functioned as active speakers and the native speakers as active listeners. On the other hand, when the topic was important, the roles were reversed in such a way that native speakers were more dominant.

Based on the observations of Ellis (2003), as developing learners' interest and motivation to negotiate for meaning is the objective of teaching and learning process, it is important to consider the significance of the topic of a task. Classroom discussions are probably the most commonly used activity types in meaning-focused tasks, the most common activity type which aims at enhancing negotiation for meaning as well as fostering fluency in oral production. There are some reasons that cause discussion skills to be underdeveloped in English classrooms.

The pressure of time, the low level of proficiency, and the large size of the class could result in a lack of discussion skills. Green, Christopher, and Lam (1997) suggest that this problem can be solved by implementing guided and structured discussions with a "framework within which learners are constrained to operate". In this way, learners are provided with the content input in advance, and they are supposed to play their roles 
based on prearranged stages, then at the end of the discussion activities, they receive their teacher's feedback on their performance (Green et al., 1997, p. 224). Although this provides a sense of security and avoids communication breakdowns through structured activities, there is a lack of direct involvement of learners in this method, and learners do not select the discussion topics themselves, nor do they choose to follow specific lines of inquiry. Moreover, they might be demotivated to engage actively in classroom discussions.

Topic interest One of the factors that influence second language acquisition (SLA) in general is learners' interest (Dörnyei, 1994). It is one of the factors that is dependent on each individual's personality, therefore it may bring in different results in various situations and contexts. According to Ellis and Barkhuizen (2005) interest plays central role in determining the methods of selecting and processing certain types of information rather than others. Researchers have also conducted studies on topic interest, that is, interest is evoked when a specific topic or theme is presented. Lee (2009) defines topic interest as the extent to which reading material is interesting enough for reader to make them focused to comprehend. In early studies, Hidi and McLaren (1991) have considered topic interest to be a form of situational interest. Others have viewed topic interest as a form of individual interest (e.g., Schiefele, 1990). Ainley, Hidi, and Berndorff (2002) provided an example to explain the ambiguity of this concept. He stated that when the title "Black Holes and Quasars," is presented to learners, those who are individually interested in astronomy will find the topic interesting because it is closely related to their individual interest. In contrast, students who are not interested in astronomy may also think that the topic is interesting. In such cases, the interest is mainly the result of situational interest factors including novelty or danger that the title conveys. Ainley et al., 2002) investigated experimentally how situational and individual factors contribute to the topic interest that readers experience (Ainley et al., 2002). Research conducted over the last 20 years has demonstrated that both readers' wellestablished individual interests and their situational interests (elicited by text segments, topics, and themes) contributed to increased comprehension and learning. A number of studies have shown that children's comprehension, inferencing, and retention is facilitated by personally interesting text segments as well as by passages written on highinterest topics (e.g., Hidi, 2001; Kintsch, 1980).

Topic familiarity The fascinating topics take learners into a discussion because the familiar topics are of fun for learners. It can be said that in those types of listening there is no problem or there is less problem with activating the relevant information (Cooper, 1988).

Learners' topic familiarity, as cited in Ellis (2003), effects on the learners' tendency to negotiate meaning. Language learners exploit their knowledge of the world to help them comprehend or produce texts. Topic familiarity is also one of the factors that have been proposed in TBLT. The familiarity of the learners with the topics of the tasks as cited in Ellis (2003), impacts on the learners' propensity to negotiate meaning. Language users or language learners make use of their knowledge of the world to help them produce or comprehend the texts. 
Different types of information are included in context and situation, for example, knowledge of the topic, information about the speakers, and the kind of relationship that speakers have. The most important point here is that if the incoming information the listener hears is unfamiliar to him, it will not his schemata and he has to rely heavily on his linguistic knowledge in comprehending the message. In spite of the fact that the listener has schema but this may not be what is expected by the speaker. Online processing of background information, contextual information, and linguistic information make comprehension and interpretation easier. When the content and the topic of the material are familiar to the listener, she/he would apply her /his prior knowledge at the same time she/he would predict the next input in order to understand successfully.

From cognitive aspects, cognitive psychologists believe that knowledge is organized in the form of schemata (Long, 1990). Background knowledge or knowledge of the world is central to the way we understand language (Anderson \& Lynch, 1988; Long, 1990). As cited by Sarandi (2010), the term prior information refers to a range of knowledge types, including our world knowledge, topic familiarity and previous experience in an area (content schemata), our expectation of the rhetoric of a text (formal schemata) (Carrell \& Eisterhold, 1983) and the information received through earlier input, usually termed as co-textual information (Brown \& Yule, 1983). By activating background knowledge, either in a top-down fashion via associative cognitive networks (Kintsch, 1998), reader or listener familiarity with text content appears to aid overall comprehension, in fact, in this process, the focus of the learners is on meaning not form of the written or spoken text. It has positive effects on reading and listening proficiency. However, according to Rahimpur and Hazar (2007), it is necessary to consider a topic familiarity as a task feature in syllabus design and materials development. So, because of its importance in TBLT, there is a need to consider the effects of topic familiarity on four language skills. Furthermore, when the L2 learners are exposed to the tasks with familiar topics or when they have prior information about the topics of the tasks to be performed, in fact, they automatically focus-on-meaning rather than form (Long, 1990; Markham \& Latham, 1987; Schmidt-Rinehart, 1994).

Topic difficulty and topic importance The topic difficulty can be one of the most significant problems that affect not only native English speakers but also hundreds of students that are learning English as a second or foreign language around the world. The main problem is that students do not understand some topics or other topics are not clear enough for them. Efforts to initiate classroom discussions of controversial topics often provoke either uncomfortable silence or unthoughtful responses from students.

Classroom discussions on difficult or delicate topics can be a potential powder keg or, conversely, a conversation killer as students, feeling awkward, choose to stay silent. From sexism to racism, genocide, politics, terrorism, and even bioethics, instructors are faced with the daunting prospect of raising extremely thorny issues and getting their students to discuss them. However, professors who've been there say that, when properly approached, these discussions can be some of the best, with students coming away with invaluable lessons learned. 
Important topics are those issues that are important to the speakers. They are the important elements that is needed to focus on in order to move forward and offer better opportunities to the students.

There has been less research on the issue of topic difficulty and topic importance in English language learning classrooms.

Iranian and international previous studies on self-selection vs. textbook-assigned topics

Pratidina and Setiyadi, (2020) investigated the effect of the self-selected topic and checklist-based peer feedback on the writing ability of students of English as a foreign language (EFL). This study involved 68 eleven-grade students of Multimedia Program of a Vocational High School at Malang, a city in the Province of East Java, Indonesia. Two intact classes assigned to be experimental and control groups. The experimental group received treatment of the self-selected topic and checklistbased peer feedback, while the control group did not. Pre-test and post-test were administered in the form of writing tests to both groups. The results showed that the students taught to write with the self-selected topic and checklist-based peer feedback outperformed those taught without using self-selected topics and checklist-based peer feedback.

Bonyadi and Zeinalpur (2014) explored EFL students' perceptions of self-selected and teacher-assigned topics in their writing classes. They used a certain form of data collection, self-written-reports, written by EFL adult students $(N=30)$, reflecting their own perceptions on the issue. The findings of the study have revealed that students, generally, perceived to be more motivated and encouraged to write when they are granted the right to choose their own selected topic in their EFL writing classes. However, a small number of them expressed their positive perceptions of teacher-assigned topics.

Horiba and Fukaya (2015) explored the effect of reading goals, topic-familiarity, and language proficiency on text comprehension and learning. EFL learners with high and low topic-familiarity read and recalled a text. Some learners had a recall task in a particular language whereas others were told of the L1 recall before reading and later recalled in the L2 (the L1-L2 condition). It was concluded that content recall was increased in the L1-L1 condition whereas incidental vocabulary learning was enhanced in the L2-L2 condition. The overall content recall was affected by language proficiency while topic-familiarity is the simplified processing of specific content information. The findings of this study suggest that resource allocation during text processing is influenced by the reading goal, where topic-familiarity and language proficiency intervene additively.

Lee and Pulido (2017) studied the impact of topic interest, alongside L2 proficiency and gender, on L2 vocabulary acquisition through reading. A repeated-measures design was used with 135 Korean EFL students. Control variables included topic familiarity, prior target-word knowledge, and target-word difficulty (word length, class, and concreteness). Participants read both high- and low-interest topic passages and took vocabulary posttests (word-form recognition, translation recognition, and translation production) immediately and 4 weeks after reading. Analyses revealed significant effects of topic interest and L2 proficiency and a significant interaction between topic interest and gender. These results were maintained over time. The article concludes by 
discussing the facilitative role of topic interest, expanding on the motivational factor considered in the involvement load hypothesis.

Sujannah and Cahyono (2017) investigate the effect of the self-selected topic and checklist-based peer feedback on the writing ability of students of English as a foreign language (EFL). This study involved 68 eleven-grade students of Multimedia Program of a Vocational High School at Malang, a city in the Province of East Java, Indonesia. Two intact classes assigned to be experimental and control groups. The experimental group received treatment of the self-selected topic and checklist-based peer feedback, while the control group did not. Pre-test and post-test were administered in the form of writing tests to both groups. The results showed that the students taught to write with self-selected topic and checklist-based peer feedback outperformed those taught without using self-selected topic and checklist-based peer feedback.

Ebrahimi and Javanbakht (2015) investigated the effect of topic interest on Iranian EFL learners' reading comprehension ability. In order to reach this aim, an experimental method was designed for data collection. Ten EFL students were randomly selected in order to find how much the learners are interested in reading texts. They answered an interest survey that was designed for this purpose. Based on students' responses regarding their interests in reading texts, the three most interesting topics were given to the control group and three least interesting topics were given to the experimental group. The reading texts were taught to learners in three sessions and learners answered their comprehension questions. The students' scores were collected and submitted for data analysis. The result of t-test showed that there is a significant difference between experimental and control group in their performance on reading comprehension texts.

In order to fill the gap in the literature, this study was an attempt to investigate the perception of textbook-assigned and self-selected topics of Iranian male EFL learners regarding topic interest, topic familiarity, topic importance, and topic difficulty.

\section{Method}

Design

The researchers employed a correlational design to investigate the participants' perception of text-book assigned and self-selected topics of Iranian male EFL Learners regarding the topic interest, topic familiarity, topic importance, and topic difficulty. The participants were selected through convenience sampling.

\section{Participants}

The participants of this study consisted of 200 Iranian male EFL learners who were studying English at the intermediate level at English language institutes in Zanjan, Iran. To select the participants, the researchers used convenience (availability) sampling. Two hundred Iranian intermediate EFL learners from twelve different classes at Jahad Daneshgahi language Institute in Zanjan constituted the population of this study. In order to have participants of approximately equal level of English language proficiency, the Preliminary English Test (PET) was administered to the sample.

Among them, intermediate learners were selected as the participants of this study. They were 200 hundred students studying eleven classes. There were about eighteen 
students in each class. The participants were males, aging from 16 to 30. A proficiency was administered to make sure that the learners are homogenous with respect to their language proficiency. A sample of Preliminary English Test was extracted from Preliminary English Test 5 of Cambridge ESOL Examinations published by Cambridge University Press (PET, 2011) and was administered to the participants in order to determine the learners' overall proficiency level in general. The intermediate level was chosen for this study as it was thought to be the average level between elementary and advanced levels. Generally, intermediate learners were able to take part in conversations to participate in social interactions. Also, it was believed that they would be able to start, continue, and finish the conversation. Intermediate learners were exposed to the English language more than elementary levels. On the other hand, choosing advanced learners as the participants of the study would have resulted in biased findings as they are fully able to communicate easily and confidently. Due to these distinctions, the intermediate level could be chosen as the safest level.

\section{Instruments}

The Textbook-assigned Topics Questionnaire (Appendix A ) and Self-selected Topics Questionnaire (Appendix B) were utilized as the instruments of this study to collect the quantitative data of the participants' perceptions of the topic interest, familiarity, importance, and difficulty assigned by their textbook and self-selected ones. However, eliciting the learners' perceptions through the questionnaires may only show their ideal attitudes. Therefore, it is required to investigate whether the learners' attitudes influence the actual classroom activities under the two conditions of textbook-assigned and self-selected topics.

\section{Procedure}

\section{Piloting the questionnaires}

The translated versions of the questionnaires were piloted to 30 English language learners, with similar characteristics to the target group in order to gather data on how the Textbook-Assigned and Self- Selected Topics Questionnaires work and also check if they suit the purpose of the study. Then, Cronbach's alpha was calculated for the questionnaires and each subscale of topic interest, topic familiarity, topic importance, and difficulty, respectively and for both Textbook-Assigned Questionnaire and SelfSelected Topics Questionnaire. According to Ölmeza (2016), the acceptable alpha value is .70, therefore, both questionnaires and their subscales were revealed to have acceptable internal consistency reliability.

\section{Main study}

The researchers first contacted the manager of the language institutes to make arrangements to distribute the two questionnaires among the participants. In order to collect data, the researchers selected the institutes based on proximity and the number of EFL learners' availability. Therefore, convenience sampling was implemented to select male EFL learners. The instruments of the study were sent to the participants via email or in-person through paper-and-pencil format. 
Regarding the data collection history and rate of return for the questionnaires, it is worth mentioning that the questionnaires were distributed in July 2019. The TextbookAssigned Topics Questionnaires were distributed 1 week after the beginning of the term. In this way, as a first step, Textbook-assigned Topics Questionnaires were distributed among the participants, which took them 20 min to complete the items. After the completion of the first questionnaire, the participants could get susceptible and provide biased and different attitudes considering the topics included in the second questionnaire, and also taking into account some practical reasons such as the learners' fatigue after the completion of the first questionnaire) which could have a negative effect on the findings of the study, they were supposed to complete Self-Selected Topics Questionnaire an interval of 1 week in a similar way. The data were collected and analyzed by SPSS22 software.

\section{Validation}

The validity of the instrument was the main feature of it which ensures the appropriateness of the questionnaires applied in the research. The questionnaires of this study were judged by some experts in English language teaching. In order to evaluate the content validity, the experts' judgment about the appropriateness of the content of the instrument, and the purpose of the research was applied. In order to evaluate the content validity of the questionnaires quantitatively the CVR (Content Validity Ratio) and CVI (Content Validity Index) coefficients were used. The questionnaires of this study were validated by 20 experts and the following content validity was estimated. It is to mention that the CVR and CVI index should be higher than 0.42 and 0.79 respectively for 20 experts.

According to Tables 1 and 2, the questionnaires have the appropriate content validity. In this table NE refers to the number of experts who indicated that the item is essential and $\mathrm{nE} 1$ is the number of experts who indicated that the item is completely related.

\section{Reliability of the instruments}

Reliability is one of the technical characteristics of research instruments. The reliability coefficient of the questionnaires should be calculated in order to determine the reliability of them. In this research, the reliability coefficient was calculated using a Cronbach's Alpha test. To do so, 30 questionnaires were distributed among participants, then according to the collected data, the Cronbach's Alpha was calculated by SPSS software. As the calculated Alpha was higher than 0.7, it showed high reliability for the questionnaire.

Table 1 Content Validity Ratio of Validated Questionnaires for Learners' Perception of Self-Selected Topics

\begin{tabular}{lcccc}
\hline Aspects & $\mathrm{n}_{\mathrm{E} 1}$ & $\mathrm{~N}_{\mathrm{E}}$ & $\mathrm{CVI}$ & $\mathrm{CVR}$ \\
\hline Interest & 17 & 18 & 0.85 & 0.80 \\
Familiarity & 18 & 15 & 0.90 & 0.55 \\
Importance & 16 & 16 & 0.80 & 0.60 \\
Difficulty & 16 & 17 & 0.80 & 0.75 \\
Questionnaire & 16 & 17 & 0.90 & 0.75 \\
\hline
\end{tabular}


Table 2 Content Validity Ratio of Validated Questionnaires for Learners' Perception of TextbookAssigned Topics

\begin{tabular}{lcccc}
\hline Aspects & $\mathrm{n}_{\mathrm{E} 1}$ & $\mathrm{~N}_{\mathrm{E}}$ & $\mathrm{CVI}$ & $\mathrm{CVR}$ \\
\hline Interest & 18 & 18 & 0.90 & 0.80 \\
Familiarity & 17 & 16 & 0.85 & 0.60 \\
Importance & 16 & 16 & 0.80 & 0.60 \\
Difficulty & 19 & 19 & 0.95 & 0.90 \\
Questionnaire & 19 & 0.80 & 0.80 \\
\hline
\end{tabular}

Table 3 shows that the Cronbach's Alpha for the self-selected topic questionnaire is higher than 0.7 which indicates that the questionnaire is reliable.

Table 4 shows that the Cronbach's Alpha for the textbook-assigned topic questionnaire is higher than 0.7 which indicates that the questionnaire is reliable.

\section{Data analysis}

In this study, the data collected through the two questionnaires was analyzed with Statistical Package for the Social Sciences (SPSS) version 22. Data coding as a prerequisite for data analysis was done by assigning values to different answers on the part of the participants and in order to come up with each person's score, the obtained values were finally summed up. Therefore, to answer the first and second research questions which aimed to depict how Iranian EFL learners generally viewed textbook-assigned topics as well as self-selected topics based on the four dimensions of topic interest, topic importance, topic difficulty, and topic knowledge, the descriptive statistics (e.g., minimum, maximum, means, and standard deviations) were calculated for each one of the questionnaires (i.e., Textbook-Assigned and Self-Selected Topics Questionnaires).

\section{Data collection procedures}

Prior to the initiation of the first step of the study, the researcher contacted the head of the language institute from which the sample was selected and after explaining the goal and specific information of the research, arrangements were made for the distribution of the two self-report questionnaires among the participants. In order to ensure that all the language learners who have registered in the course are present in the classrooms, the Textbook-Assigned Topics Questionnaires were distributed 1 week after the beginning of the term. It took them 20 min to complete the items. Bearing in mind the fact that after completing the first questionnaire, the participants could get sensitized and, as a result, provide different and sometimes biased attitudes regarding the topics included in the second questionnaire, and also considering some practical reasons (e.g.,

Table 3 Cronbach's Alpha Test for the Self-Selected Topics Questionnaire

\begin{tabular}{lll}
\hline & N of Items & Cronbach's Alpha \\
\hline Interest & 48 & 0.702 \\
Familiarity & 48 & 0.752 \\
Importance & 48 & 0.701 \\
Difficulty & 48 & 0.689 \\
Questionnaire & 192 & 0.741 \\
\hline
\end{tabular}


Table 4 Cronbach's Alpha Test for the Textbook Assigned Topics Questionnaire

\begin{tabular}{lll}
\hline & N of Items & Cronbach's Alpha \\
\hline Interest & 48 & 0.704 \\
Familiarity & 48 & 0.699 \\
Importance & 48 & 0.701 \\
Difficulty & 48 & 0.725 \\
Questionnaire & 192 & 0.906 \\
\hline
\end{tabular}

the participants' fatigue after completing the first questionnaire) which could affect the results of the study negatively, they were asked to complete the Self-Selected Topics Questionnaire in a similar way after an interval of 2 weeks. While the questionnaires were being distributed among the participants, the researcher herself, who was also their teacher and the participants were already familiar with her, was present in the classroom and provided detailed instructions on how to respond to the items in each one of the questionnaires. The researcher also ensured the participants that the research responses would not have any effect on their evaluation and guaranteed the confidentiality of their responses, which would merely serve for research purposes.

\section{Results}

\section{Descriptive analysis of the first research question}

In the present research, the main dimensions of the research were the topic interest, familiarity, importance, and difficulty in self-selected topics questionnaire and the dimensions of the topic interest, familiarity, importance, and difficulty in textbook-assigned topics questionnaire. The following tables show the central indicators and the distribution of the answers to the questions related to each of the variables.

First the research question was about how Iranian EFL male learners generally view textbook-assigned topics based on the four dimensions of topic interest, topic familiarity, topic importance, and topic difficulty?

In relation to Table 5, the mean scores for the participants' perceptions of textbookassigned topics along with the four dimensions of topic interest, familiarity, importance, and difficulty were $3.220,3.225,3.04$, and 3.01 respectively. Based on the values of skewness and Kurtosis which is between the range of 2 and -2, the variables have been distributed normally.

This table contains the overall mean scores for these four dimensions. The analysis of the results revealed that the learners' perceptions of topic interest $(M=3.220)$ and topic familiarity $(M=3.225)$ exceeded their perceptions of topic importance $(M=3.04)$ and topic difficulty $(M=3.01)$. This means that the participants tended to judge the textbook-assigned topics primarily based on the extent to which they proved to be

Table 5 Descriptive Statistics for Learners' Perception of the Textbook-Assigned Topics

\begin{tabular}{llllll}
\hline & mean & Median & Std. Deviation & Skewness & Kurtosis \\
\hline interest & 3.2209 & 3.708 & .23815 & .675 & -.218 \\
familiarity & 3.2255 & 3.990 & .24602 & 1.863 & .351 \\
importance & 3.0407 & 3.541 & .22402 & .750 & -.038 \\
difficulty & 3.0165 & 3.479 & .24183 & .121 & -.083 \\
\hline
\end{tabular}


Table 6 Descriptive Statistics for Learners' Perception of the Self-Selected Topics

\begin{tabular}{llllll}
\hline & mean & Median & Std. Deviation & Skewness & Kurtosis \\
\hline Interest & 4.0345 & 3.708 & .16153 & .824 & -.161 \\
familiarity & 4.3859 & 3.990 & .17516 & 8.686 & 1.421 \\
importance & 3.9563 & 3.541 & .17777 & 2.601 & .214 \\
Difficulty & 3.8357 & 3.479 & .18524 & -.497 & -.250 \\
\hline
\end{tabular}

interesting and familiar enough so that they could develop them in their English language classes. The higher values of the standard deviations of the least two measures might also mean that the learners were less confident in judging the difficulty and importance of the topics.

\section{Descriptive analysis of the second research question}

The second research question was about how Iranian EFL male learners generally view self-selected topics based on the four dimensions of topic interest, topic familiarity, topic importance, and topic difficulty?

Along with Table 6, the mean scores for the participants' perceptions of self-selected topics along with the four dimensions of topic interest, familiarity, importance, and difficulty were $4.034,4.38,3.95$, and 3.83 respectively. Based on the values of skewness and Kurtosis which is between the range of 2 and -2, the variables have been distributed normally.

In comparison to the first research question which intended to investigate how the participants perceived textbook-assigned topics, the second research question was set out to elicit the participants' perceptions of the topics they could select themselves. As can be seen from Table 6, the analysis of the participants' perceptions of self-selected topics along with the four dimensions of topic interest, familiarity, importance, and difficulty showed higher mean scores for learners' perceptions of topical interest and topical familiarity. In other words, in comparison to the reported mean scores for topic importance $(M=3.95)$ and topic difficulty $(M=3.83)$, the learners' reported mean scores were found to be higher for topic interest $(M=4.034)$ and topic familiarity $(M=4.38)$.

Therefore, similar to their perceptions of textbook-assigned topics, Iranian EFL learners approached the self-selected topics by prioritizing their interest in and knowledge about discussing them in their English language classes over the topics' importance and difficulty.

In keeping with Table 7, the mean score for the participants' perceptions of selfselected topics was 4.053, and the mean score for the participants' perceptions of textbook-assigned topics was 3.126 Based on the values of skewness and Kurtosis which is between the range of 2 and-2, the variables have been distributed normally.

Table 7 The Mean Score for the Participants' Perceptions of Self- Selected Topics and TextbookAssigned Topics

\begin{tabular}{llllll}
\hline & mean & Median & Std. Deviation & Skewness & Kurtosis \\
\hline Self-selected topics & 4.0531 & 4.063 & .411 & -.158 & .13334 \\
Textbook-assigned topics & 3.1259 & 3.126 & .341 & -.250 & .21553 \\
\hline
\end{tabular}




\section{Data analysis of the third research question}

Regarding the third research question which examines if there is any significant difference between the learners' perceptions of textbook-assigned and self-selected discussion topics, and the way they differ, the following hypothesis was introduced.

$H 0$ (1): There are no significant differences between Iranian male EFL learners' perceptions of textbook-assigned and self-selected topics along the four dimensions of topic interest, topic familiarity, topic importance, and topic difficulty.

According to the abovementioned hypothesis, there will be four sub-hypotheses which will be dealt with and the results will be discussed.

Sub-hypothesis 1: There is a significant difference between Iranian male EFL learners' perceptions of textbook-assigned and self-selected topics along the dimension of the topic interest.

In order to test this sub-hypothesis first we have:

H0: There is no a significant difference between Iranian male EFL learners' perceptions of textbook-assigned and self-selected topics along the dimension of the topic interest. H1: There is a significant difference between Iranian male EFL learners' perceptions of textbook-assigned and self-selected topics along the dimension of topic interest.

In accordance with Table 8, the Levene's test was applied to test the equality of the variances. As Table 8 shows, the Sig value is 0.000 which is lower than 0.05 , the equality of the variances is rejected. Based on the results of the t-test regarding the topic interest, the Sig value is 0.000 which is lower than 0.05 , H0 that is the equality of the means is rejected at a $95 \%$ confidence level. In other words, there is a significant difference between the mean of the learner's perception of the textbook-assigned topics and self-selected topics regarding the topic interest. Table 9 shows the mean values:

In relation to the Table 9, the mean of the learners' perception of the selfselected topics regarding the topic interest is 4.0345 which is higher than the mean of the learners' perception of textbook-assigned topics that is 3.2209 regarding the topic interest.

Table 8 The Results of T-Test to Compare the Results of Learners' Perception of TextbookAssigned and Self-Selected Topics Regarding Topic Interest

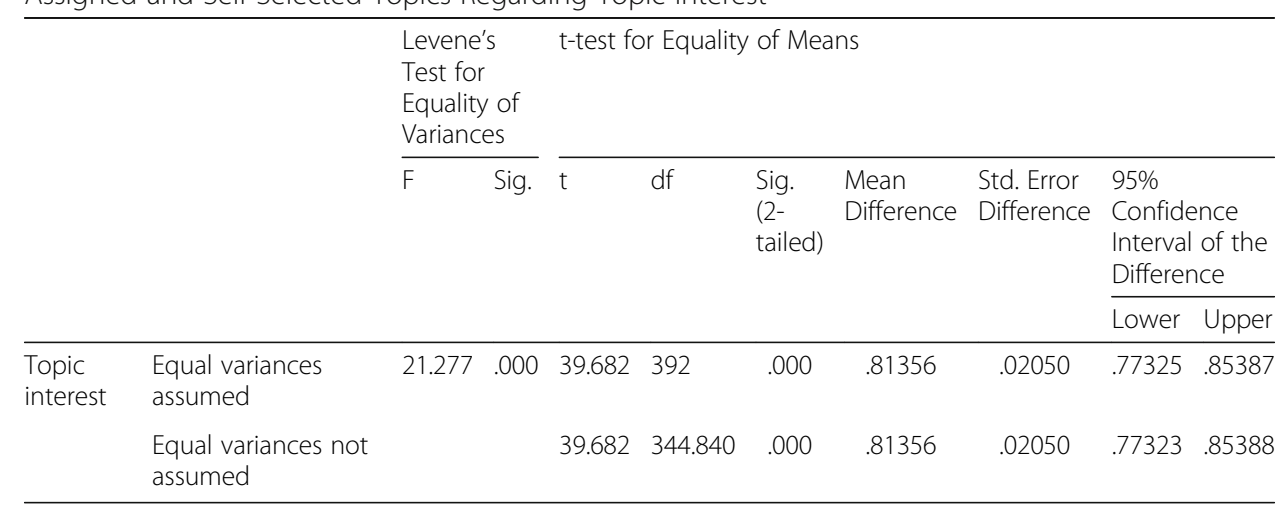


Table 9 The Mean Values of The Learner's Perception of the Textbook-Assigned Topics and SelfSelected Topics Regarding the Topic of Interest

\begin{tabular}{llllll}
\hline & Group & N & Mean & Std. Deviation & Std. Error Mean \\
\hline Topic interest & Self-selected topics & 197 & 4.0345 & .16153 & .01151 \\
& Textbook-assigned topics & 197 & 3.2209 & .23815 & .01697 \\
\hline
\end{tabular}

Sub-hypothesis 2: There is a significant difference between Iranian male EFL learners' perceptions of textbook-assigned and self-selected topics along the dimension of topic familiarity.

In order to test this sub-hypothesis first we have:

HO: There is no significant difference between Iranian male EFL learners' perceptions of textbook-assigned and self-selected topics along the dimension of topic familiarity. H1: There is a significant difference between Iranian male EFL learners' perceptions of textbook-assigned and self-selected topics along the dimension of topic familiarity.

Consistent with the Table 10, the Levene's test was applied to test the equality of the variances. As Table 10 shows, the Sig value is 0.000 which is lower than 0.05 , the equality of the variances is rejected. Based on the results of the t-test regarding the topic familiarity, the Sig value is 0.000 which is lower than $0.05, \mathrm{H} 0$ that is the equality of the means is rejected at a $95 \%$ confidence level. In other words, there is a significant difference between the mean of the learner's perception of the textbook-assigned topics and self-selected topics regarding the topic familiarity. Table 11 shows the mean values:

Based on Table 11. The mean of the learners' perception of the self-selected topics regarding the topic familiarity is 4.3859 which is higher than the mean of the learners' perception of textbook-assigned topics that is 3.2255 regarding the topic of a familiarity.

Sub-hypothesis 3: There is a significant difference between Iranian male EFL learners' perceptions of textbook-assigned and self-selected topics along the dimension of the topic importance.

In order to test this sub-hypothesis first we have:

Table 10 The Results of T-Test To Compare the Results of Learners' Perception of TextbookAssigned and Self-Selected Topics Regarding Topic Familiarity

\begin{tabular}{|c|c|c|c|c|c|c|c|c|c|c|}
\hline & & \multicolumn{2}{|c|}{$\begin{array}{l}\text { Levene's Test } \\
\text { for Equality of } \\
\text { Variances }\end{array}$} & \multicolumn{7}{|c|}{ t-test for Equality of Means } \\
\hline & & \multirow[t]{2}{*}{$\bar{F}$} & \multirow[t]{2}{*}{ Sig. } & \multirow[t]{2}{*}{$\bar{T}$} & \multirow[t]{2}{*}{$\mathrm{df}$} & \multirow[t]{2}{*}{$\begin{array}{l}\text { Sig. } \\
\text { (2-tailed) }\end{array}$} & \multirow[t]{2}{*}{$\begin{array}{l}\text { Mean } \\
\text { Difference }\end{array}$} & \multirow[t]{2}{*}{$\begin{array}{l}\text { Std. Error } \\
\text { Difference }\end{array}$} & \multicolumn{2}{|c|}{$\begin{array}{l}\text { 95\% Confidence } \\
\text { Interval of the } \\
\text { Difference }\end{array}$} \\
\hline & & & & & & & & & Lower & Upper \\
\hline \multirow[t]{2}{*}{$\begin{array}{l}\text { Topic } \\
\text { familiarity }\end{array}$} & $\begin{array}{l}\text { Equal variances } \\
\text { assumed }\end{array}$ & 17.669 & .000 & 53.931 & 392 & .000 & 1.16043 & .02152 & 1.11812 & 1.20273 \\
\hline & $\begin{array}{l}\text { Equal variances } \\
\text { not assumed }\end{array}$ & & & 53.931 & 354.086 & .000 & 1.16043 & .02152 & 1.11811 & 1.20274 \\
\hline
\end{tabular}


Table 11 The Mean Values of the Learner's Perception of the Textbook-Assigned Topics and SelfSelected Topics Regarding the Topic of Familiarity

\begin{tabular}{llllll}
\hline & Group & N & Mean & Std. Deviation & Std. Error Mean \\
\hline Topic familiarity & Self-selected topics & 197 & 4.3859 & .17516 & .01248 \\
& Text-book-assigned topics & 197 & 3.2255 & .24602 & .01753 \\
\hline
\end{tabular}

H0: There is no significant difference between Iranian male EFL learners' perceptions of textbook-assigned and self-selected topics along the dimension of topic importance. H1: There is a significant difference between Iranian male EFL learners' perceptions of textbook-assigned and self-selected topics along the dimension of topic importance.

According to the Table 12, the Levene's test was applied to test the equality of the variances. As Table 12 shows, the Sig value is 0.000 which is lower than 0.05 , the equality of the variances is rejected. Based on the results of the t-test regarding the topic importance, the Sig value is 0.000 which is lower than 0.05 , H0 that is the equality of the means is rejected at a $\% 95 \%$ confidence level. In other words, there is a significant difference between the mean of the learner's perception of the textbook-assigned topics and self-selected topics regarding the topic importance. Table 13 shows the mean values:

As stated by the Table 13, the mean of the learners' perception of the self-selected topics regarding the topic importance is 3.9563 which is higher than the mean of the learners' perception of textbook-assigned topics that is 3.0407 regarding the topic importance.

Sub-hypothesis 4: There is a significant difference between Iranian male EFL learners' perceptions of textbook-assigned and self-selected topics along the dimension of the topic difficulty.

In order to test this sub-hypothesis first we have:

HO: There is no significant difference between Iranian male EFL learners' perceptions of textbook-assigned and self-selected topics along the dimension of topic difficulty. H1: There is a significant difference between Iranian male EFL learners' perceptions of textbook-assigned and self-selected topics along the dimension of topic difficulty.

Table 12 The results of t-test to compare the results of learners' perception of textbook-assigned and self-selected topics regarding topic importance

\begin{tabular}{|c|c|c|c|c|c|c|c|c|c|c|}
\hline & & \multicolumn{2}{|c|}{$\begin{array}{l}\text { Levene's Test } \\
\text { for Equality of } \\
\text { Variances }\end{array}$} & \multicolumn{7}{|c|}{ t-test for Equality of Means } \\
\hline & & \multirow[t]{2}{*}{$\mathrm{F}$} & \multirow[t]{2}{*}{ Sig. } & \multirow[t]{2}{*}{$t$} & \multirow[t]{2}{*}{$d f$} & \multirow[t]{2}{*}{$\begin{array}{l}\text { Sig. } \\
\text { (2-tailed) }\end{array}$} & \multirow[t]{2}{*}{$\begin{array}{l}\text { Mean } \\
\text { Difference }\end{array}$} & \multirow[t]{2}{*}{$\begin{array}{l}\text { Std. Error } \\
\text { Difference }\end{array}$} & \multicolumn{2}{|c|}{$\begin{array}{l}95 \% \text { Confidence } \\
\text { Interval of the } \\
\text { Difference }\end{array}$} \\
\hline & & & & & & & & & Lower & Upper \\
\hline \multirow[t]{2}{*}{$\begin{array}{l}\text { Topic } \\
\text { importance }\end{array}$} & $\begin{array}{l}\text { Equal variances } \\
\text { assumed }\end{array}$ & 9.638 & .002 & 44.937 & 392 & .000 & .91561 & .02038 & .87555 & .95567 \\
\hline & $\begin{array}{l}\text { Equal variances } \\
\text { not assumed }\end{array}$ & & & 44.937 & 372.758 & .000 & .91561 & .02038 & .87554 & .95567 \\
\hline
\end{tabular}


Table 13 The Mean Values of the Learner's Perception of the Textbook-Assigned Topics and SelfSelected Topics Regarding the Topic Importance

\begin{tabular}{llllll}
\hline & Group & N & Mean & Std. Deviation & Std. Error Mean \\
\hline Topic importance & Self-selected topics & 197 & 3.9563 & .17777 & .01267 \\
& Textbook-assigned topics & 197 & 3.0407 & .22402 & .01596 \\
\hline
\end{tabular}

In accordance with Table 14, the Levene's test was applied to test the equality of the variances. As Table 14 shows, the Sig value is 0.000 which is lower than 0.05 , the equality of the variances is rejected. Based on the results of the t-test regarding the topic difficulty, the Sig value is 0.000 which is lower than $0.05, \mathrm{H} 0$ that is the equality of the means is rejected at a $95 \%$ confidence level. In other words, there is a significant difference between the mean of the learner's perception of the textbook-assigned topics and self-selected topics regarding the topic difficulty. Table 15 shows the mean values:

In proportion to Table 15, The mean of the learners' perception of the self-selected topics regarding the topic difficulty is 3.835 which is higher than the mean of the learners' perception of textbook-assigned topics that is 3.0165 regarding the topic difficulty.

As it is clear in this Table, there was a significant difference between the learners' perceptions of textbook-assigned and self-selected topics with regard to their perceived levels of topic interest and topic familiarity. As to the topic importance, and the topic difficulty, however, there was no significant difference between the participants' perceptions of textbook-assigned and self-selected topics. In general, based on the results of the t-tests, it can be concluded that learners tended to have more interest in and knowledge about discussing the topics they could select themselves, rather than the topics which were assigned to them by their textbook.

\section{Data analysis of the fourth research question}

Considering the fourth research question investigating which condition (i.e. textbook assigned or self-selected tasks) contribute more to the better understanding of the discussion topics, the following hypotheses were presented:

H0: There is no significant difference between Iranian male EFL learners' perceptions of textbook-assigned and self-selected topics along with the four dimensions of topic interest, topic familiarity, topic importance, and topic difficulty.

Table 14 The Results of T-Test to Compare the Results of Learners' Perception of TextbookAssigned and Self-Selected Topics Regarding Topic Difficulty

\begin{tabular}{|c|c|c|c|c|c|c|c|c|c|c|}
\hline & & \multicolumn{2}{|c|}{$\begin{array}{l}\text { Levene's } \\
\text { Test for } \\
\text { Equality of } \\
\text { Variances }\end{array}$} & \multicolumn{7}{|c|}{ t-test for Equality of Means } \\
\hline & & \multirow[t]{2}{*}{$\bar{F}$} & \multirow[t]{2}{*}{ Sig. } & \multirow[t]{2}{*}{$\mathrm{t}$} & \multirow[t]{2}{*}{$\mathrm{df}$} & \multirow[t]{2}{*}{$\begin{array}{l}\text { Sig. } \\
\text { (2-tailed) }\end{array}$} & \multirow[t]{2}{*}{$\begin{array}{l}\text { Mean } \\
\text { Difference }\end{array}$} & \multirow[t]{2}{*}{$\begin{array}{l}\text { Std. Error } \\
\text { Difference }\end{array}$} & \multicolumn{2}{|c|}{$\begin{array}{l}95 \% \text { Confidence } \\
\text { Interval of the } \\
\text { Difference }\end{array}$} \\
\hline & & & & & & & & & Lower & Upper \\
\hline \multirow[t]{2}{*}{$\begin{array}{l}\text { Topic } \\
\text { difficulty }\end{array}$} & $\begin{array}{l}\text { Equal variances } \\
\text { assumed }\end{array}$ & 7.965 & .005 & 37.743 & 392 & .000 & .81916 & .02170 & .77649 & .86183 \\
\hline & $\begin{array}{l}\text { Equal variances } \\
\text { not assumed }\end{array}$ & & & 37.743 & 367.096 & .000 & .81916 & .02170 & .77648 & .86184 \\
\hline
\end{tabular}


Table 15 The Mean Values of the Learner's Perception of the Textbook-Assigned Topics and SelfSelected Topics Regarding the Topic Difficulty

\begin{tabular}{llllll}
\hline & Group & N & Mean & Std. Deviation & Std. Error Mean \\
\hline Topic difficulty & Self-selected topics & 197 & 3.8357 & .18524 & .01320 \\
& Textbook-assigned topics & 197 & 3.0165 & .24183 & .01723 \\
\hline
\end{tabular}

H1: There is a significant difference between Iranian male EFL learners' perceptions of textbook-assigned and self-selected topics along with the four dimensions of topic interest, topic familiarity, topic importance, and topic difficulty.

In order to test the fourth hypothesis, as the data was normal, the t-test was applied for two sets of the data and the results of it have been provided below.

Along with Table 16, the Levene's test was applied to test the equality of the variances. As Table 16 shows, the Sig value is 0.000 which is lower than 0.05 , the equality of the variances is rejected. Based on the results of the t-test regarding the topic interest, familiarity, importance, and difficulty, the Sig value is 0.000 which is lower than $0.05, \mathrm{H} 0$ that is the equality of the means is rejected at $95 \%$ confidence level. In other words, there is a significant difference between the mean of the learner's perception of the textbook-assigned topics and self-selected topics regarding the topic interest, familiarity, importance, and difficulty. Table 17 shows the mean values:

According to Table 17. The mean of the learners' perception of the self-selected topics regarding the four dimensions is 4.0531 which is higher than the mean of the learners' perception of textbook-assigned topics that is 3.1259 regarding the topic interest, familiarity, importance, and difficulty.

\section{Discussion}

\section{Research question one}

How do Iranian EFL male learners generally view textbook-assigned topics based on the four dimensions of topic interest, topic familiarity, topic importance, and topic difficulty?

Table 16 The Results of T-Test to Compare the Results of Learners' Perception of TextbookAssigned and Self-Selected Topics Regarding Topic Interest, Familiarity, Importance, and Difficulty

\begin{tabular}{|c|c|c|c|c|c|c|c|c|c|c|}
\hline & & \multicolumn{2}{|c|}{$\begin{array}{l}\text { Levene's } \\
\text { Test for } \\
\text { Equality of } \\
\text { Variances }\end{array}$} & \multicolumn{7}{|c|}{ t-test for Equality of Means } \\
\hline & & \multirow[t]{2}{*}{$\mathrm{F}$} & \multirow[t]{2}{*}{ Sig. } & \multirow[t]{2}{*}{$t$} & \multirow[t]{2}{*}{$\mathrm{df}$} & \multirow[t]{2}{*}{$\begin{array}{l}\text { Sig. } \\
\text { (2-tailed) }\end{array}$} & \multirow[t]{2}{*}{$\begin{array}{l}\text { Mean } \\
\text { Difference }\end{array}$} & \multirow[t]{2}{*}{$\begin{array}{l}\text { Std. Error } \\
\text { Difference }\end{array}$} & \multicolumn{2}{|c|}{$\begin{array}{l}95 \% \text { Confidence } \\
\text { Interval of the } \\
\text { Difference }\end{array}$} \\
\hline & & & & & & & & & Lower & Upper \\
\hline \multirow{2}{*}{$\begin{array}{l}\text { Self-selected } \\
\text { and textbook } \\
\text { assigned } \\
\text { topics }\end{array}$} & $\begin{array}{l}\text { Equal variances } \\
\text { assumed }\end{array}$ & \multirow[t]{2}{*}{35.190} & \multirow[t]{2}{*}{.000} & 51.348 & 392 & .000 & .92719 & .01806 & .89169 & .96269 \\
\hline & $\begin{array}{l}\text { Equal variances } \\
\text { not assumed }\end{array}$ & & & 51.348 & 326.855 & .000 & .92719 & .01806 & .89167 & .96271 \\
\hline
\end{tabular}


Table 17 The Mean Values of the Learner's Perception of the Textbook-Assigned Topics and SelfSelected Topics Regarding the Topic Interest, Familiarity, Importance, and Difficult

\begin{tabular}{lllll}
\hline Group & N & Mean & Std. Deviation & Std. Error Mean \\
\hline Self-selected topics & 197 & 4.0531 & .13334 & .00950 \\
Textbook-assigned topics & 197 & 3.1259 & .21553 & .01536 \\
\hline
\end{tabular}

The participants of this study were 200 Iranian male EFL learners aged 16 to 32 years old. They were all intermediate level learners, they were studying English as a foreign language in language institutes in Zanjan, Iran.

In order to investigate the learners' perceptions of textbook-assigned and selfselected topics, the researcher distributed two questionnaires among the participants. They were asked to answer the questionnaires regarding topic interest, familiarity, importance, and difficulty in self-selected and text-book-assigned topics.

The analysis of the obtained data for the first research question of the study revealed that Iranian male EFL learners' perceptions of topic interest and topic familiarity surpassed their perceptions of topic importance and topic difficulty in textbook-assigned topics. This means that the participants tended to show more excitement in textbookassigned topics which were more interesting and familiar due to the fact that they could develop these topics in their English language classes. The topics were primarily judged based on the participants' interest and familiarity with them and secondarily based on their perceived importance or difficulty. This reveals that the learners preferred the topics in which they were interested and about which their background knowledge would suffice.

Interestingly, the findings of this study were parallel with previous studies which had findings in common with this research: (e.g., Wolf, 2013; Bonyadi, 2014; Threadkell, 2010; Lee, 2009; Kang, 2005; Sewell, 2003; Schraw et al., 2001; Schiefele, 1990; Tobias, 1994; Kragler, 2000). The results of these studies have revealed that learners' interests play an important role in English language classes.

\section{Research question two}

How do Iranian EFL male learners generally view self-selected topics based on the four dimensions of topic interest, topic familiarity, topic importance, and topic difficulty?

Regarding the perceptions of self-selected topics, Iranian male EFL learners prioritized their interest in and knowledge about discussing them in their English classes over the topics' importance or difficulty.

With regard to the self-selected topics, learners' interest in and knowledge about discussion topics in English language classes played a more significant role than the topic importance or difficulty. Therefore, it can be discussed that topic interest can have a strong and significant role in motivating learners toward initiating discussions. Learners would feel more motivated to learn the language and take part willingly in interesting activities. This finding is in line with the findings of some conducted studies such as (e.g., Bonyadi, 2014; Wolf, 2013; Threadkell, 2010; Lee, 2009; Kang, 2005; Sewell, 2003; Schraw et al., 2001; Tobias, 1994; Schiefele, 1990) the results of which highlighted the importance of topic interest and familiarity. 
Furthermore, background knowledge about discussion topics can be considered as support, which can simplify the language learning process. In fact, background knowledge of learners about the topics makes them feel confident enough to initiate the discussion and share their ideas with other members. This finding is also consistent with the results obtained from some other conducted previous studies (e.g., Bonyadi \& Zeinalpur, 2014; Bonyadi, 2014; Wolf, 2013; Cao \& Philp, 2006; Kang, 2005; Kang, 2005; Gradwohl \& Schumacher, 1989) which have given prominence to the role of background knowledge in facilitating the interaction in a foreign language.

\section{Research question three}

Is there any significant difference between the learners' perceptions of textbookassigned and self-selected discussion topics? If so, how do they differ?

Regarding Iranian EFL learners' perceptions of textbook-assigned and self-selected topics based on the four dimensions of topic interest, familiarity, importance, and the difficulty, the findings of this study indicated that their learners' perceived topic interest and familiarity to be more significant than topic importance and difficulty. Accordingly, the null hypothesis stating that there is no significant difference between Iranian male EFL learners' perceptions of textbook-assigned and self-selected topics can be rejected partially based on the results of this study which indicated a significant difference between the learners' perceptions of textbook-assigned and self-selected topics long with four dimensions of topic interest and familiarity dimensions, importance, and difficulty.

Another an interesting finding of this study was that the participants' perception of topic importance and difficulty when discussing textbook-assigned topics in comparison with self-selected topics was not so significant. Moreover, learners should find lower levels of difficulty in discussing interesting and familiar topics in English classes. However, the findings of this study do not back up these assumptions. Feasibly, it was more difficult for participants to scrutinize topic importance and difficulty since they cannot judge them according to their own capabilities in discussions. Regarding the topic difficulty and topic importance, other factors might prevail in learners' making judgments about the topics' difficulty and importance. This area requires more research to determine and examine some other influential factors that might have an influence on the perceptions of the learners regarding these two factors.

\section{Research question four}

Which condition (i.e. textbook assigned or self-selected tasks) contribute more to a better understanding of the discussion topics?

Actually, Iranian male EFL learners move toward the importance of interest in and familiarity with self-selected topics compared with textbook-assigned topics. In fact, due to the general nature of self-selected topics, the learners could be provided with the chance to select and concentrate on certain points about topics in which they had more interests. In addition, since self-selected topics were related to learners' experiences, personal lives, contextual, and cultural values, they were highly personalized and localized.

Moreover, it is to mention that self-selected topics were more related to the Iranian context in terms of learners' culture, experiences, lifestyles, needs, values, and concerns 
textbook-assigned topics, which were generally designed for various learners from all over the world.

Therefore, due to the compatible and interesting nature of the self-selected topics, it can be discussed that these topics were more preferable for learners to talk about, which were more suited to their personal lifestyle, experience, values, and needs. Consequently, participants showed more interest in the topics chosen by themselves. These findings are in line with the findings of some previous similar studies such as Wolf (2013), and Bonyadi (2014), Threadkell (2010), which have empirically investigated the learners' perceptions of textbook-assigned and self-selected topics and eventually, concluded that the participants showed positive attitudes about discussing self-selected topics.

\section{Conclusion}

The overall findings of this study have been reviewed in this section. This study sought to explore Iranian male EFL learners' perception of textbook-assigned and self-selected topics regarding four dimensions of topic interest, topic familiarity, topic importance, and topic difficulty. Based on four research questions of this study, four main conclusions are as following:

1. Considering the textbook-assigned topics, Iranian EFL learners' perceived topic interest and topic familiarity to be of high importance than topic importance and topic difficulty. In other words, the participants judged the topics assigned by their textbooks based on their being interesting and familiar, so that they could develop these topics in their English language classes.

2. Taking into account the learners' perceptions of self-selected topics, Iranian EFL learners put more importance on their interest in and knowledge about discussing topics in their English classes than the topics' importance or difficulty.

3. In consideration of Iranian male EFL learners' perceptions of textbook-assigned and self-selected topics based on the four dimensions of topic interest, familiarity, importance, and the difficulty, there was a significant difference between the learners' perceptions of textbook-assigned and self-selected topics in terms of interest, familiarity, importance, and difficulty.

4. The results of this study revealed that learners have significantly more tendencies to talk about interesting and familiar topics, which is mostly present in the topics they could choose themselves rather than topics assigned by their there is no a significant difference between Iranian textbooks.

\section{Supplementary information}

Supplementary information accompanies this paper at https://doi.org/10.1186/s40862-020-00099-7.

Additional file 1: Appendix A. Learners' Perceptions of Textbook-Assigned Topics Questionnaire. Appendix B. Learners' Perceptions of Self-Selected Topics Questionnaire.

\section{Abbreviations}

EFL: English foreign language; CLT: Communicative Language Teaching; TBLT: Task Based Language Teaching; CVR: Content Validity Ratio; CVI: Content Validity Index 


\section{Authors' contributions}

All authors of the research had more or less equal contributions in the process of conception, design, acquisition of data, analysis and interpretation of data. They have all been involved in revising the manuscript critically to the same extent. All take public responsibility for the whole content. All are equally accountable for all aspects of the work. The authors read and approved the final manuscript.

\section{Funding}

The study did not receive any funding.

\section{Availability of data and materials}

The data will be available upon requesting.

\section{Competing interests}

The authors declare that they have no competing interests.

Received: 16 April 2020 Accepted: 23 August 2020

Published online: 22 October 2020

\section{References}

Ainley, M., Hidi, S., \& Berndorff, D. (2002). Interest, learning, and the psychological processes that mediate their relationship. Journal of Educational Psychology, 94(3), 545.

Amiri, F., \& Saberi, L. (2019). The impact of the learner-centered approach on Learners' motivation in Iranian EFL students. International Academic Journal of Social Sciences, 6(1), 155-165. https://doi.org/10.9756/IAJSS/v611/1910015.

Anderson, A., \& Lynch, T. (1988). Listening. Oxford University Press, England.

Anderson, J. (2020). 'Buying into communicative language teaching: The impact of 'initial certification courses on the classroom practices of experienced teachers of English. Innovation in Language Learning and Teaching, 14(1), 1-14. https://doi.org/10.1080/17501229.2018.1471082.

Barkhuizen, G. P. (1998). Discovering learners' perceptions of ESL classroom teaching/learning activities in a south African context. TESOL Quarterly, 32, 85-107. https://doi.org/10.2307/3587903.

Benson, P. (2003). Learner autonomy in the classroom. In D. Nunan (Ed.), Practical English language teaching, (pp. 289-308). New York: McGraw-Hill.

Benson, P. (2007). Autonomy in language teaching and learning. Language Teaching, 40(1), 21-40. https://doi.org/10.1017/ S0261444806003958.

Beschorner, B., \& Woodward, L. (2020). Engaging teachers in a digital learner-centered approach to support understanding foundational literacy. In Effective practices in online teacher preparation for literacy educators, (pp. 284-306). IGI global, USA.

Bonyadi, A. (2014). The effect of topic selection on EFL students' writing performance. Sage Open Journal Retrieved December 4, 2014, from http://sgo.sagepub.com/content/4/3/2158244014547176.

Bonyadi, A., \& Zeinalpur, S. (2014). Perceptions of students towards self-selected and teacher-assigned topics in EFL writing. Procedia-Social and Behavioral Sciences, 98, 385-391.

Brown, G., \& Yule, G. (1983). Discourse analysis. Cambridge university press, United Kingdom.

Cao, Y., \& Philp, J. (2006). Interactional context and willingness to communicate: Comparison of behavior in whole class, group, and dyadic interaction. System, 34, 480-493. https://doi.org/10.1016/j.system.2006.05.002.

Carrell, P. L., \& Eisterhold, J. C. (1983). Schema theory and ESL reading pedagogy. TESOL Quarterly, 17(4), 553-573. https://doi. org/10.2307/3586613.

Choi, J., Lee, J. H., \& Kim, B. (2019). How does learner-centered education affect teacher self-efficacy? The case of projectbased learning in Korea. Teaching and Teacher Education, 85, 45-57. https://doi.org/10.1016/j.tate.2019.05.005.

Cooper, M. (1988). NIU listening exam: Assessing college level listening skills. International Listening Association. Journal, 2(1), $53-74$.

Dörnyei, Z. (1994). Motivation and motivating in the foreign language classroom. Modern Language Journal, 78, 273-284.

Ebrahimi, S., \& Javanbakht, Z. O. (2015). The effect of topic interest on Iranian EFL learners' Reading comprehension ability. Journal of Applied Linguistics and Language Research, 2(6), 80-86.

Ellis, R. (2003). Task-based language teaching and learning. Oxford: Oxford University Press.

Ellis, R., \& Barkhuizen, G. (2005). Analyzing learner language. Oxford: Oxford University Press.

Gradwohl, J. M., \& Schumacher, G. M. (1989). The relationship between content knowledge and topic choice in writing. Written Communication, 6, 181-195.

Green, C. F., Christopher, E. R., \& Lam, J. (1997). Developing discussion skills in the ESL classroom. ELT Journal, 51, 135-143.

Hidi, S. (2001). Interest, reading, and learning: Theoretical and practical considerations. Educational Psychology Review, 13(3), 191-209. https://doi.org/10.1023/A:1016667621114.

Hidi, S. E., \& McLaren, J. A. (1991). Motivational factors and writing: The role of topic interestingness. European journal of psychology of education, 6(2), 187-197.

Horiba, Y., \& Fukaya, K. (2015). Reading and learning from L2 text: Effects of Reading goal, topic familiarity, and language proficiency. Reading in a Foreign Language, 27(1), 22-46.

Kang, S. J. (2005). Dynamic emergence of situational willingness to communicate in a second language. System, 33, $277-292$. https://doi.org/10.1016/j.system.2004.10.004.

Kintsch, W. (1980). Learning from text, levels of comprehension, or: Why anyone would read a story anyway. Poetics, 9(1-3), $87-98$.

Kintsch, W. (1998). Comprehension: A paradigm for cognition. Cambridge University Press, United Kindom.

Kojima, H. (2005). Teacher roles in learner-centered communicative EFL instruction. Bulletin of the Faculty of Education, Hirosaki University, 94, 59-71.

Kragler, S. (2000). Choosing books for reading: An analysis of three types of readers. Journal of Research in Childhood Education, 14(2), 133-141. https://doi.org/10.1080/02568540009594758. 
Kumaravadivelu, B. (1991). Language-learning tasks: Teacher intention and learner interpretation. ELT Journal, 45, 98-107. https://doi.org/10.1093/elt/45.2.98.

Lee, S., \& Pulido, D. (2017). The impact of topic interest, L2 proficiency, and gender on EFL incidental vocabulary acquisition through reading. Language Teaching Research, 21(1), 118-135. https://doi.org/10.1177/1362168816637381.

Lee, S. K. (2009). Topic congruence and topic interest: How do they affect second language reading comprehension? Reading in a Foreign Language, 21(2), 159-178.

Long, D. R. (1990). What you don't know can't help you: An exploratory study of background knowledge and second language listening comprehension. Studies in Second Language Acquisition, 12(1), 65-80. https://doi.org/10.1017/ S0272263100008743.

Markham, P., \& Latham, M. (1987). The influence of religion-specific background knowledge on the listening comprehension of adult second-language students. Language Learning, 37(2), 157-170. https://doi.org/10.1111/j.1467-1770.1987.tb00563.x.

Matsuyama, Y., Nakaya, M., Okazaki, H., Lebowitz, A. J., Leppink, J., \& Van Der Vleuten, C. (2019). Does changing from a teacher-centered to a learner-centered context promote self-regulated learning: a qualitative study in a Japanese undergraduate setting. BMC medical education, 19(1), 1-12.

Narayanan, N. (2020). Improving Indian Teachers' readiness to adopt new methodologies: Role of learner-centered in-service training. International Journal of Teacher Education and Professional Development (IJTEPD), 3(1), 102-120. https://doi.org/10. 4018/IJTEPD.2020010107.

Nunan, D. (1989). Designing tasks for the communicative classroom. Cambridge: Cambridge University Press.

Nunan, D. (2005). Important tasks of English education: Asia-wide and beyond. In P. Robertson, P. Dash, \& J. Jung (Eds.), English language learning in the Asian context, (pp. 5-8). Pusan: The Asian EFL Journal Press.

Nunan, D., \& Lamb, C. (1996). The self-directed teacher: Managing the learning process. Cambridge: Cambridge University Press.

Ölmeza, F. (2016). Exploring the interaction of $L 2$ Reading comprehension with text $Y$ and learner $Y$ related factors. Social and Behavioral Science, 232(14), 719-727. https://doi.org/10.1016/j.sbspro.2016.10.098.

Pratidina, A. T., \& Setiyadi, B. (2020). Developing A Teaching Model through Students-Selected Topics and Implicit Corrective Feedback in Teaching Writing. U-JET, 9(1), 17-34.

Rahimpur, M., \& Hazar, F. (2007). Topic familiarity effect on accuracy, complexity, and fluency of L2 oral production. The Journal of Asia TEFL, 4, 191-211.

Sarandi, H. (2010). Content related support and listening comprehension: Some limitations. Procedia-Social and Behavioral Sciences, 2(2), 5605-5611.

Schiefele, U. (1990). The influence of topic interest, prior knowledge, and cognitive capabilities on text comprehrension. In J. M. Pieters, K. Breuer, \& P. R. J. Simons (Eds.), Learning environments, (pp. 323-337). Berlin: Springer.

Schmidt-Rinehart, B. C. (1994). The effects of topic familiarity on second language listening comprehension. The Modern Language Journal, 78(2), 179-189. https://doi.org/10.1111/j.1540-4781.1994.tb02030.x.

Schraw, G., Flowerday, T., \& Lehman, S. (2001). Increasing situational interest in the classroom. Educational Psychology Review, $13,211-224$.

Sujannah, W. D., \& Cahyono, B. Y. (2017). The effect of self-selected topic and checklist-based peer feedback on Indonesian EFL students' writing ability. International Journal of English Lanquage Teaching, 4(2), 1-17.

Sewell, E. J. (2003). Students' Choice of Books during Self-Selected Reading. EDRS opinion papers. Retrieved March 9, 2014 from http://search.ebscohost.com/login.aspx?direct=true\&db=eric\&AN=ED476400\&site=ehost-live.

Threadkell, J. E. (2010). Seeking new perspectives on self -selected and teacher-assigned texts: Exploring adolescent readers' experiences (unpublished doctoral dissertation). Canada: University of Manitoba.

Tobias, S. (1994). Interest, prior knowledge, and learning. Review of Educational Research, 64, 37-54. https://doi.org/10.3102/ 00346543064001037.

Tunali, S. (2019). Inferences from variety of implementations in learner centered approach. Elementary Education Online, 19(1), 157-172. https://doi.org/10.17051/ilkonline.2020.649371.

Üzüm, B., \& Pesen, A. (2019). Do the learner-centered approaches increase academic performance? Effect of the layered curriculum on Students' academic achievement in English lesson. International Journal of Instruction, 12(1), 1585-1608. https://doi.org/10.29333/iji.2019.121101a.

Wolf, J. P. (2013). Exploring and contrasting EFL learners' perceptions of textbook-assigned and self-selected discussion topics. Language Teaching Research, 17(1), 49-66. https://doi.org/10.1177/1362168812457535.

Zuengler, J., \& Bent, B. (1991). Relative knowledge of content domain: An influence on native-nonnative conversations. Applied Linguistics, 12(4), 397-415.

\section{Publisher's Note}

Springer Nature remains neutral with regard to jurisdictional claims in published maps and institutional affiliations. 